\title{
Morphology and Histology of the Female Reproductive System of Abedusl ovatus Stal (Belostomatidae: Hemiptera: Insecta)|
}

\section{TG Lalitha $^{+}$, K Shyamasundari, K Hanumantha Rao}

\author{
Department of Zoology, Andhra University, Visakhapatnam-530 003, A.P.J India
}

In Abedus ovatus Stal the female reproductive system consists of a pair of ovaries leading to oviduct and opens out by genital aperture. Each ovary is composed of five telotrophic ovarioles, with four 1 different regions, terminal filament, germarium, vitellarium und pedicel. Germarium and vitellarium are the germ tubes in which the development of oocyte occurs. In the germarium, the differentiation of trophocytes into young oocytes was observed in three zones, $Z_{I} \mid Z_{I \mid}$ and $Z_{I I I}$ Further development of oocytes in the vitellarium could be divided into seven stages, $S T,-S T_{V I I}$ The developed eggs are lodged in the pedicel.

Key words: ovary - germarium - vitellarium - oocytes

Morphological and histological studies on reproductive system of insects have called the attention of several investigators (Snodgrass 1935, Bonhag 1958, Davey 1965, Wigglesworth 1965). Information on the oogenesis of Popilus| disjunctus Illiger, Laccotrephes maculates Fahr. Oncopeltus fasciatus Dallas, Schistocerca gregarid Forskol, Dytiscus, Cybister and Hygrobia and Triatoma infestana Klug were given by Bryan (1954), Bonhag (1958), Nath et al. (1959), Lusis (1963), Urbani (1970) and Barth (1973) respectively. Choi Won Chul and Walter (1976) made electron microscopic studies on the differentiation and development of trophocytes and oocytes in Gerris najas De Geer. Later the histological details of the ovarian structure is given by Deshpande and Srivastava (198 1) in Dysdercus Koenigii Fabr and Ma and Ramaswamy in Lygus Zineolaris. Hamilton (193 1) and Kaushik (1972) contributed information on genitalia of Nepa cinerea Linn and Belostoma indicum Lep and Serv.

Abedus ovatus is a freshwater bug with slightly greenish hue and transluscent body measures: 20-25 mm in length. They commonly lurks among the phytal fauna in pools and ponds and its favourate resting position is to cling to some support with the tip of the abdomen. The most interesting and characteristic feature of this bug is that the female species lay their eggs on the back of the

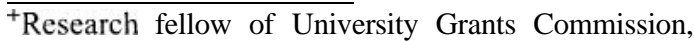
New Delhi, and corresponding author. Fax: +91-891 $-555547$

Received 13 November 1995

Accepted 19 August 1996
}

males and these encumbered males carry their eggs till they hatch. Females swimming in a rather ungainly manner and males with eggs on the back have called our attention to study the morphological and histological studies of the female reproductive system.

\section{MATERIALS AND METHODS}

Adult specimens were collected from Kondakarla Lake, $40 \mathrm{~km}$ from Visakhapatnam and maintained in the aquarium tanks in the laboratory. Visakhapatnam is located on the east coast of India between latitude $17^{\circ} 42^{\prime} \mathrm{N}$ and longitude $82^{\circ} 181 \mathrm{E}$. Ten female specimens were dissected for reproductive system and the material was fixed immediately in Susa or Zenker or $10 \%$ formalin or formoll calcium. After processing $8 \mathrm{pm}$ thick sections were cut in sagittal and transverse planes and the sections were stained with Azan and Mallory triple stain (Barth 1953, Pearse 1968) techniques for their histological study. The study material is deposited in the Museum, Zoology Department, Andhra University, Visakhapatnam, Register No.1979.

\section{RESULTS}

The female reproductive system of $A$. ovatus consists of a pair of ovaries which lie ventro-laterally in the body cavity of the abdomen on either side of the alimentary canal. Each ovary is composed of live telotrophic ovarioles, which are attached to the dorsal wall of the anterior prothorax by apical filaments. Posteriorly the ovarioles join to form a short lateral oviduct which inturnl leads into a central median oviduct and opens out by female genital opening. The median oviduct receives a duct from paragenital organ (Fig. 1). 

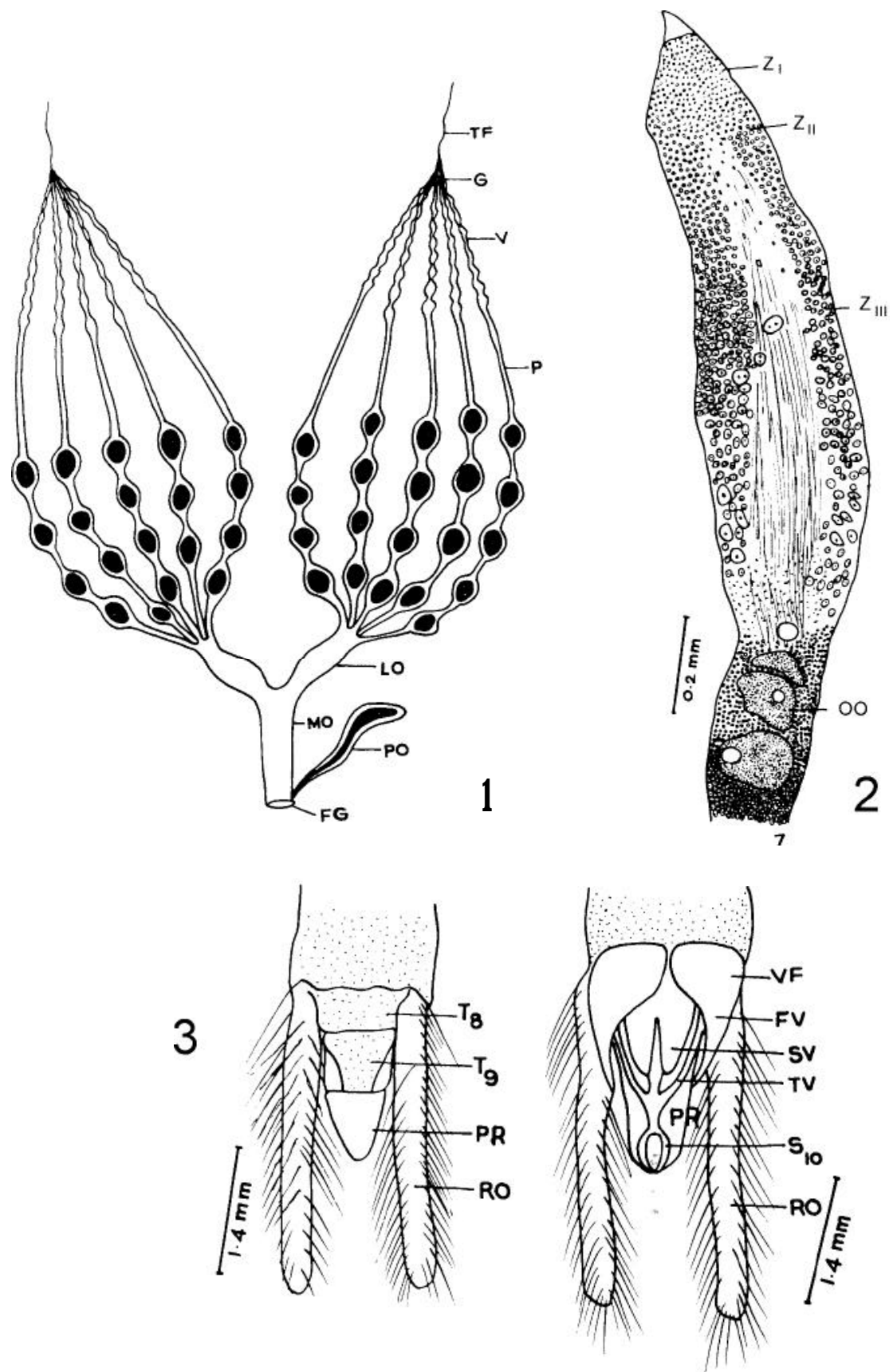

Fig. I female reproductive system. TF: terminal filament. G: gennarium. V: vitellarium. P: pedicel. LO: lateral oviduct. MO: median oviduct. PO: paragenital organ. FG: female genital opening. Fig. 2 ! longitudinal section of the germarium. $Z_{1} \nmid$ zone-1. $\mathrm{Z}_{\mathrm{II}}\{$ zone-IIJZ $\mathrm{III}\{\mathrm{zone-IIJ}$ 00: young oocytes. Fig. 3: genitalia (dorsal and ventral views). FV: first valvulae. PR: procttger. RO: retractile organ. SV: second valvulae. $\mathrm{S}_{10}$ t sternal segment. TV: third valvulae. $\mathrm{T}_{81} \mathrm{~T}$,: tergal segments. VF: first valvifer.

Each ovariole is composed of four main re-1 gions: (1) the thread-like apical filament, (2) the germarium, a chamber housing anteriorly the nurse cells and posteriorly the young oocytes, (3) a long vitellarium composed of a series of oocytes in their follicular sheaths, which become progressively large towards the posterior end, and (4) the pedicel in which the mature eggs are lodged before passing into the lateral oviduct.

Genitalia is formed by the modification of eighth and ninth abdominal segments. The ovipositor is constituted by three pairs of compressed plate-like 
valvulae and one pair of valvifer, each articulating with a small basal sclerite on the eighth and ninth tergum with lateral retractile organ and a central protiger covered with tenth sternum (Fig. 3).

The germarium is the most anterior chamber of the ovariole and it contains trophocytes, young oocytes and prefollicular tissue. A large portion of the anterior of the germarium is occupied by trophocytes, the apical position of the trophocytes is typical of the Hemiptera and for this reason the ovarioles of these insects are termed telotrophic ovarioles. In A.ovatus three zones, zone-I, zone-II and zone-111 could be recognized in the trophic region (Fig. 2).

Zone-I is the most anterior region and is characterized by small cells with scanty cytoplasm and spherical nuclei. Mitotic figures are found anteriorly in this zone, indicating the site for the origin of new trophocytes. Some of the nuclei have conspicuous and peripherally arranged condensed chromatin bodies.

Zone-11 is distinguished by its large cells which are three or four times the diameter of zone-1 cells. They are irregular in shape. The nuclei are ovoid or angular and contain condensed chromatin bodies.

Zone-III occupies more than two thirds of the trophocyte region and contains fully differentiated trophic tissue. This zone is characterized by the presence of branching strands of cytoplasmic material which eventually converge centrally and posteriorly to form an elongate trophic core. These strands are often extensions of intact cells and they apparently serve as pathways for the flow of material from degenerating cells into the trophic core. In the longitudinal section of the trophic core, longitudinal striations were observed throughout its length suggesting a fibrillar or lamellar| composition (Fig. 4).

In the anterior region of this zone, the cells are larger than those of zone-II. The size of the cells increases towards the posterior region and in their greatest dimensions they average approximately five times the diameter of zone- 1 cells. Their nuclei are similarly enlarged with rod or oval shape. Binucleate cells are found in this zone.

From the posterior end of the trophic core, the nutritive cords radiates and join the prefollicular chamber (Fig. 5). These cords originate as small connecting strands between the base of the core and the youngest oocytes which are situated at the anterior border of the prefollicular region. Larger cords are connected with the most posterior $00-1$ cytes and maintain their continuity with the oocytes as they move posteriorly into the vitellarium. Like the trophic core its branches are longitudinally striated.
In the most posterior region of the germarium, the oocytes are small and spherical with large amounts of cytoplasm with a single nucleus (Fig. 6 ). The ooplasm of the young oocytes is homogenously granular with a centrally located nuclei. This condition persists throughout the stages, where the oocytes are surrounded by two or three layered epithelium. During the previtelline period the oocyte grows and elongates. Yolk has been observed peripherally in the oocytes as small globular spheres. In the young oocytes the nucleus is spherical and centrally located. As the oocyte further enlarge, the nuclei develop into germinal vesicle and increases in size due to the accumulation of vesicular fluid.

The oocytes development in the vitellarium could be divided into seven stages (ST,-ST,,,). In stage-1 (Fig. 7) the follicular epithelium is multilayered and undergoes rapid division of growth. The oocytes measure up to $46.3 \times 2.1 \mu \mathrm{m}$ in diameter. The ooplasm is finely granular and its nucleus is spherical and more or less located in the centre.

In stage-II (Fig. 7) the follicular epithelium is double layered in this stage. The oocytes measure $101.4 \times 66.3 \mu \mathrm{m}$ in diameter with a finely granulated cytoplasm. The seminal vesicle increases in size which is situated towards the periphery.

In stage-III (Fig. 8) the follicular cells are arranged in a single row. The ooplasm is finely granular with peripherally placed yolk granules, which are seen as small spherical spheres. The oocyte measures up to $202.8 \times 128.7 \mu \mathrm{m}$ in diameter. Transparent spheres are sometimes observed in the region where the nutritive cords enter the oocytes.

In stage-IV (Fig. 10) the follicular cells become cuboidal at this stage. The oocyte measures $269.1 \mathrm{x}$ $206.7 \mu \mathrm{m}$ in diameter. Large and small dense droplets and spheres are seen in the peripheral ooplasm.

In stage-V (Fig. 9) binucleate columnar cells are observed in the epithelium. The oocyte measures up to $400 \times 160 \mu \mathrm{m}$ | in diameter. The yolk droplets and spheres increases in size and number. Small droplets are oriented towards the periphery of the ooplasm.

In stage-VI (Fig. 11) the follicle cells are squamous and binucleate. The oocyte is ellipsoidal in shape, measures about $608 \times 224 \mu \mathrm{m}$ in diameter. The ooplasm is completely filled with yolk droplets.

In stage-VII (Fig. 12) the sqamous cells of the epithelium become vacuolated and begin to breakdown. Formation of chorion layer is completed by the end of the vitellogenesis. The oocyte is packed with large yolk spheres and measures 672 x 320 $\mu \mathrm{m}$ in diameter. It shows tremendous increase in size before vitellogenesis. 

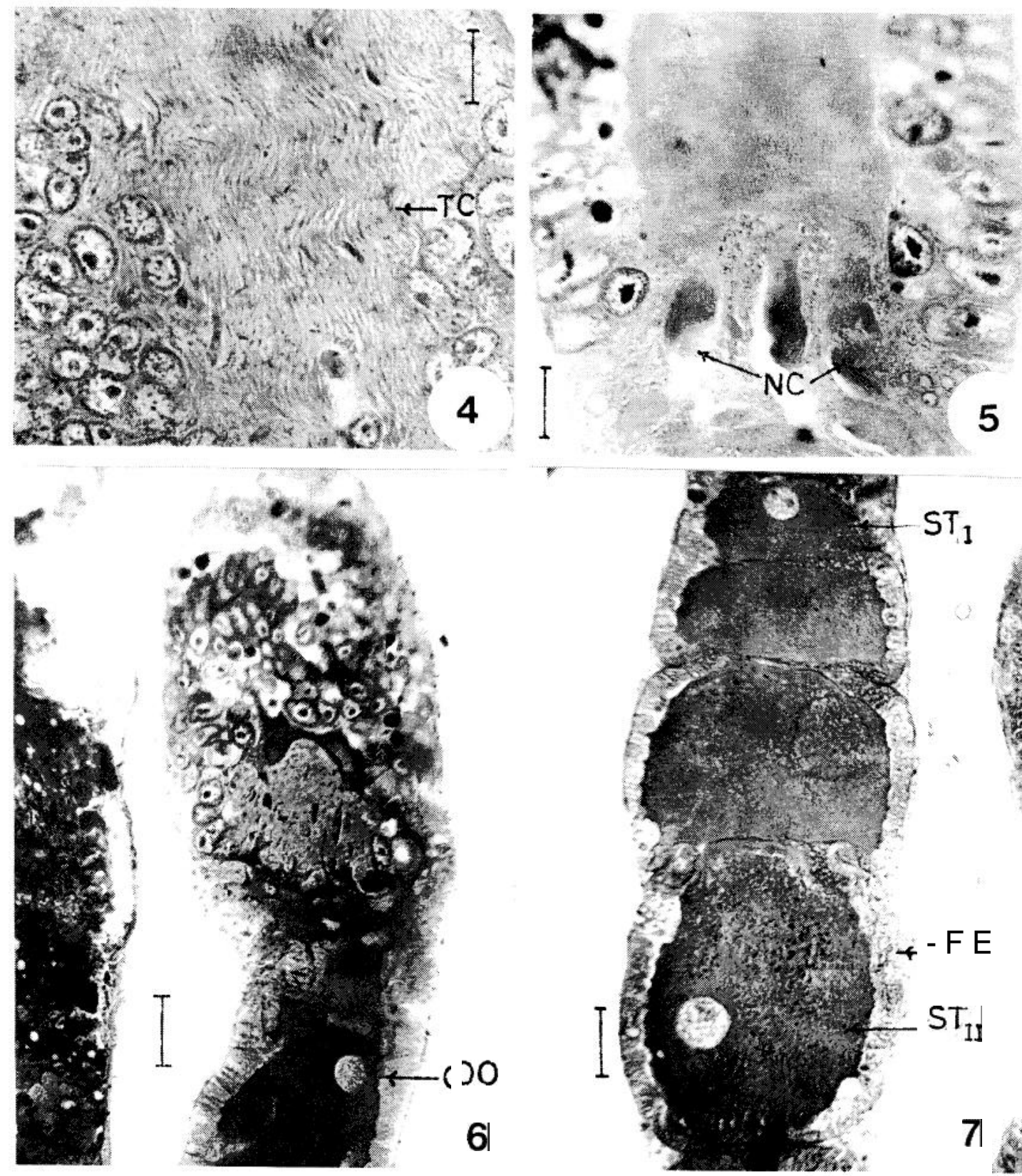

Fig. 4: trophic core showing its tibrillar nature. TC: trophic core. Bar $60 \mu \mathrm{m}$ Fig. 5: posterior region of the germarium showing the presence of nutritive cords (NC). Bar $15 \mu \mathrm{m}$, Fig. 6: longititudinal section of the ovariole showing the formation of young oocytes (00). Bar $15 \mu$ m. Fig. 7: longitudinal section of vitellarium showing stage-1 (ST,) and stage-11 (ST,,) oocytes. FE: follicular epithelium. Bar $25 \mu \mathrm{m}$.

The follicular plug develops as a mass of cells in the developing oocytes of the vitellarium. As the oocytes development progresses the follicular cells extend spread all around the oocytes, thus separating the two successive oocytes.

The pedicel is a simple tube, which lodges the developed eggs and connects vitellarium and the lateral oviduct. The wall of the pedicel shows the presence of squamous cells whose nuclei are ovoid and small in comparison with those of the follicular epithelium and contain homogeneously distrib-1 uted chromatin granules. 


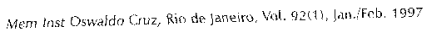
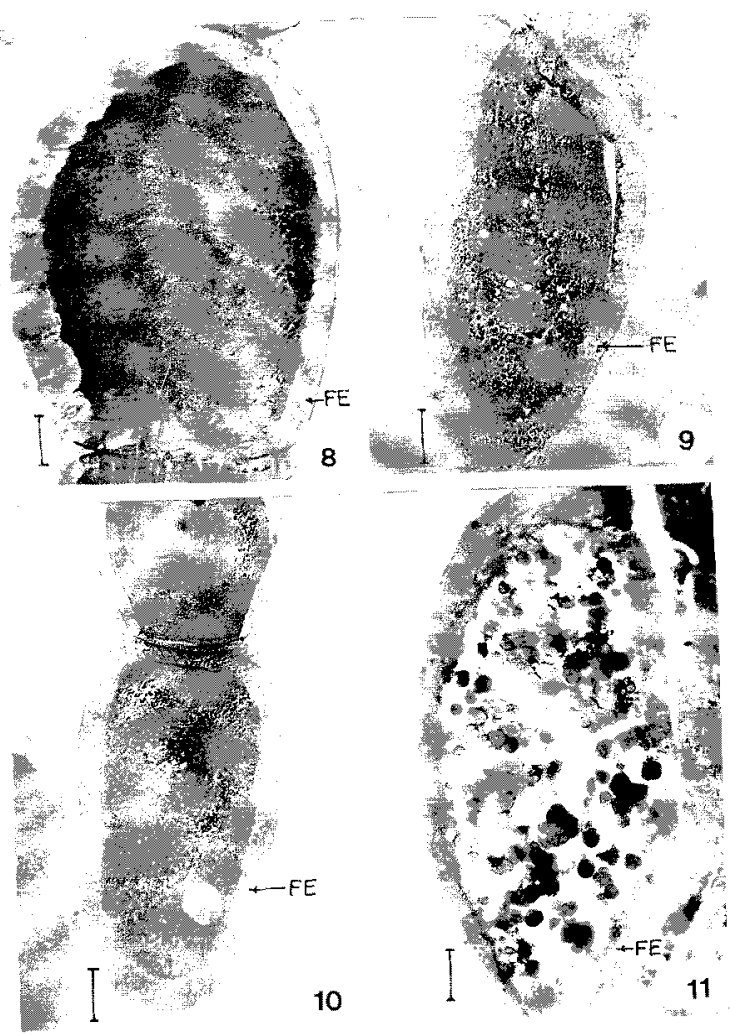

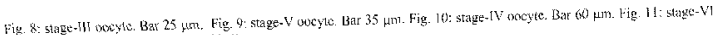

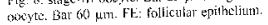




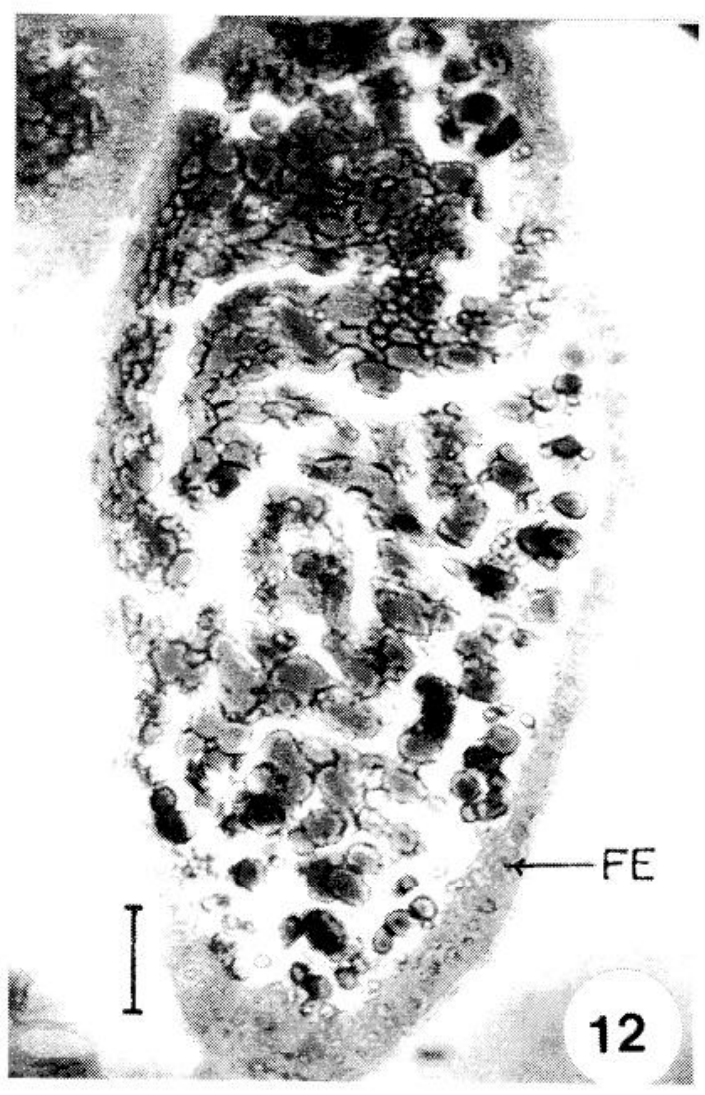

Fig. 12: stage VIIl oocyte. FE: follicular epithelium. Bar $60 \mu \mathrm{m}$,

\section{DISCUSSION}

In A. ovatus, the female reproductive system consists of a pair of ovaries situated on the ventral side of the abdomen on either side of the alimentary canal. Each ovariole is composed of five telotrophic ovarioles, leading to lateral oviduct which unite posteriorly to form a common oviduct. Anteriorly five ovarioles are joined by terminal filament by which they are attached to the abdomen. Each ovariole is composed of a slender terminal filament, germarium, vitellarium and pedicel. The germarium and vitellarium are the germ tubes in which the development of the egg takes place. The developed eggs are lodged in pedicel. The general organization is in agreement with the reproductive system of other hemipterans like Oncopeltus fasciatus (Bonhag \&l Wick 1953), Rhodnius prolixus Stal (Vanderberg 1963), Gerris regimis Say (Eschenberg \& Dunlap 1966) and Dysdercus|fasciatus Gign (Brunt 1971). Ma and Ramaswamy (1987) who followed the histological changes during first gbnotrophic cycle, states that there are three distinct stages, previtellogenic, vitellogenic and choreogenic. Sareen et al. (I 990) could make out six zones $\left(Z_{1}-Z_{6}\right)$ including the terminal filament in Lepisma saccharina $\mathrm{L}$. The general morphology of the female genitalia in A. ovatus is in agreement with the description of the genitalia of other hemipterans (Hamilton 193 II Kaushik 1972).

Mitotic figures have been observed in the anterior zone of the germarium of the ovariole of A. ovatus, indicating as it is the site of the origin of new trophocytes. Same reports were encountered in 0. fasciatus by Bonhag (1958), R. prolixus by Vanderberg (1963) and Gerris remigis by Eschenberg and Dunlap (1966) but however, this report is in contrast to that observed by Davis (1956) in Cimex lectularis Linn.

In most of the insects germarium is very active in the production of nurse cells a phenomenon which is a continuous process. In the germarium of $A\rfloor$ ovatus the presence of cytoplasmic units with one or two prominent nuclei were observed as reported by Das Gupta and Ray (1954) in Cimex. However, syncytial character of this region has been observed by Schrader and Leutchenberger (1952) in Acanthocephala and by Bonhag and Wick (1953) in 0. fasciatus. Longitudinal striations were observed in trophic core of the germarium of $A\rfloor$ ovatus. The striated conditions of the trophic core is reported in Adelphocoris lineolatus Goeze (Masner 1966) and in D!fasciatus (Brunt 197 1). In A」 ovatus, the nutritive cords were connected to the developing oocytes, which are originated from trophic core. Nutritive cords development was reported in other insects like Popilius disjunctus (Bryan 1971).

In A. ovatus, the pre-follicular tissue migrates posteriorly into multilayered columnar epithelium which surrounds young oocytes and later give rise to the follicular epithelial cells. Brunt (197 1) reported the same findings in D. fasciatus. Binucle-t ate condition is observed in the follicular epithelial cells in the vitellarium of A. ovatus as it is reported in 0. fasciatus (Bonhag \& Wick 1953).

\section{ACKNOWLEDGEMENTS}

To Andhra University authorities for providing facilities to work.

\section{REFERENCES}

Barth R 1953. Métodol de trabalho em anatomia e histologia entomologica. Mem Inst Oswaldd Cruzl 51: 9.5-l 86.

Barth R 1973. Estudos anatômicos e histológicos sobre a sub-familia Triatominae (Heteroptera, Reduviidae). Partel XXIII. 0 ováriol de Triatomal infestans. Mem Inst Oswaldo Cruz 71: 123-137.

Bonhag PF 1958. Ovarian structure and vitellogenesis in insects. Ann Rev Ent 3: $137 \dashv 160$. 
Bonhag PF, Wick J 1953. The functional anatomy of thd male and female reproductive system of milk weed bug, Oncopeltus fasciatus (Dallas). J Morphol 93: 177-284]

Brunt AM 197 II The histology of the first batch of eggs and other associated tissue in ovariole of Dysdercus fasciatus (Hemiptera: Pyrhocoridae) as seen with the light microscopef $J$ Morphol 134: 105-129]

Bryan JHD 1954. Cytological and cytochemical studies of oogenesis of Popilius|disjunctus (Illiger)(Coleoptcra: polyphaga). Biol Bull Lancaster 107: 64-79.

Choi Won Chul, Walter N 1976. Patterns of DNA and RNA synthesis during the development of ovarian nurse cells in Gerris najas (Heteroptera). Dev Biol 16: $262-272$.

Das Gupta B, Ray HN 1954. A cytochemistry study of the nurse cells of bed bug. Proc Zool Soc Bengal 7: 107-l 12.

Davey KG 1965. Reproduction in insects. Oliver and Boyd, Edinburg, 96 pp.

Davis NT 1956. The morphology and functional anatomy of the male and female reproductive system of $\mathrm{Ci}$ mexlectularis L. Ann Ent Sod Amer 49: 466-493.

Deshpande DJ, Srivastava KP 1981. Histology and histochemical studies on the ovaries of the red cotton bg Dysdercus koenigid (Heteroptera: Pyrrhocoridae). Z Mikrosh Anat Forsch (Leipz) 95: 1035-1047.

Eschenberg KM, Dunlap HL 1966. The histology and histochemistry of oogenesis in the water strider Gerris remigis Say. J Morphol I I81297-3 16.

Hamilton MA 193 1. The morphology of water scorpion, Nepa cinerea Linn. (Rhynchota: Heteroptera). Prod Zool Sod Lond III: 1067-l 137.

Kaushik SC 1972. On the morphology of the gaint wa- ter bug, Belostoma indicum Lep. and Serv. (Heteroptera: Belostomatidae). IX. Functional morphology of the abdomen, male and female genitalia. J Anim Morphol Physiol 19: 93-1 IO.

Lusid 0 1963. The histology and histochemistry of development and reabsorption in the terminal oocytes of the desert locust, Schistocerca gregaria.Quart Л Micros Sci 1041 29-48.

Ma Wk, Ramaswamy SB 1987. Histological changes during ovarian maturation in the tarnished plant bug, Lygus lineolarist (Hemiptera: Miridae). Int J Insect Morphol Embryol 161 304-322」

Masner P 1966. The structure, function and imaginal development of the female inner reproductive organs of Adelphocorid lineolatus (Goeze) (Heteroptera: Miridae). Acta Ent Bohemosloy 63: 177-199.

Nath V, Gupta B, Sareen ML 1959. Histochemistry of vitellogenesis in water scorpions, Laccotrephes maculatus Fahr. and L. ruher C. Res Bull Punjab Univ Sci New Sar 10: 375-389.

Pearse AGE 1968. Histochemistry. Theoretical and applied. Churchill, London, Vol. 1, 998 pp.

Sareen ML, Mittall PK, Raj Sharma 1990. Vitellogenesis in Lepisma saccharina L-A cytochemical study. Uttar Pradesh J Zool IO: 124-127.

Snodgrass RE 1935. Principles of insect morphology. McGraw Hill, New York and London, 667 pp.

Urbanil E 1970. A survey of some aspects of oogenesis in Dytiscus, Cybister and Hygrohia (Coleoptera). Acta Embryd Exp 3: 28 l-297.

Vanderberg JP 1963. Synthesis and transfer of DNA and RNA protein during vitellogenesis in Rhodnius prolixus|(Hemiptera). Biol Bull 125: 556-575.

Wigglesworth VB 1965. Theprinciples of insect physiology, 6 ed. Button, New York, 434 pp. 